\title{
Influence of Soil pH and Moisture on the Viability of Sclerotia of S. rolfsii
}

\author{
B. Raghavendra*, T. Srinivas and B. Padmodaya \\ Department of Plant Pathology, S.V. Agricultural College, Tirupati-517502, \\ Andhra Pradesh, India \\ *Corresponding author
}

\section{A B S T R A C T}

\begin{tabular}{|l|}
\hline K e y w o r d s \\
$\begin{array}{l}\text { Sclerotium rolfsii, } \\
\text { Moisture, Viability } \\
\text { and Germination }\end{array}$ \\
\hline Article Info \\
\hline $\begin{array}{l}\text { Accepted: } \\
\text { 04 July 2018 } \\
\text { Available Online: } \\
\text { 10 August } 2018\end{array}$ \\
\hline
\end{tabular}

\section{Introduction}

Groundnut (Arachis hypogaea L.) is an important oil seed crop suitable for cultivation in tropical areas of the world. It is regarded as "King of oilseed crops" on account of its diversified uses. Groundnut is third largest oil seed crop grown in world and second in India. Groundnut seeds are rich in oil $(43-55 \%)$ as well as protein (25-28\%) and also contains 18 per cent carbohydrates. It can supply about 5.6 and 5.8 calories per gram of kernel in the raw and roasted forms respectively. It is also very good source of minerals (calcium, magnesium and iron) and vitamins (B1, B2 and Niacin). Groundnut being a legume crop, it fixes a large amount of nitrogen and improves the fertility status of the soil. Groundnut cake is used as animal feed and the shell sometimes used as fodder.

The groundnut production in India was 71.8 lakh tons in 2015-16. There were 9 States having groundnut production of more than 1 lakh ton viz. Gujarat, Rajasthan, Tamil Nadu, Andhra Pradesh, Karnataka, Madhya Pradesh, Maharashtra, West Bengal and Telangana in 2015-16. Gujarat was the leading producer of groundnut with 28.9 lakh tons in 2015-16 followed by Rajasthan 10.41 lakh tons and Andhra Pradesh ranks $4^{\text {th }}$ leading producer in India with 7.88 lakh tons in 2015-16. It increased by 2.95 lakh tons as compared to the groundnut production of 4.93 lakh tons in the year 2014-15. Thus, the annual growth recorded in the year 2015-16 was 
59.84\% (Source: Production of Groundnut from 2013-14 to 2015-16 from Ministry of Agriculture and Farmers Welfare).

The low productivity of groundnut in India was attributed to several biotic and abiotic factors. Groundnut is susceptible to wide range of microorganisms which include fungi, viruses, mycoplasma, nematodes and bacteria (Khirood and Paramjit Kaur, 2013). Among them, stem rot caused by Sclerotium rolfsii Sacc. is a major problem and is an economically important soil borne pathogen. It causes pod yield losses of $10-25 \%$, but under severe diseased conditions yield losses may range up to $80 \%$ (Rodriguez Kabana et al., 1975). Stem rot is a persistent soil borne disease throughout India and its incidence is increasing even at maturity stage of the groundnut crop. Though $S$. rolfsii survives both on seed and in soil, a greater threat is posed by soil borne inoculum (Kumar et al., 2013). S. rolfsii forms brownish sclerotia that can survive for long periods in the soil and retain their viability by tolerating biological and chemical degradation due to the presence of melanin in the outer membrane (Chet, 1975). S. rolfsii is a necrotrophic soil borne fungal pathogen, which has a very wide host range and distributed worldwide in warm climates (Aycock, 1966).

S. rolfsii was first reported on tomato by Rolfs (1892) and later the pathogen was named as Sclerotium rolfsii by Saccardo (1911). Higgiens (1927) worked in detail on physiology and parasitism of $S$. rolfsii. This was the first detailed and comprehensive study in USA. It is distributed in tropical and subtropical regions of the world where high temperatures prevail. The fungus has a wide host range of 500 species in about 100 families including groundnut, green bean, lima bean, onion, garden bean, pepper, potato, sweet potato, tomato and water melon (Aycock, 1966).
Stem rot of groundnut has become one of the major constraints in recent years. Management of stem rot disease is difficult because of its soil borne nature and the chemical methods are very expensive and will not be that good affect against the pathogen.

In view of unsatisfactory results by chemical methods, considerable attention has been given on the other non-chemical means of plant disease control i.e., the integration of biological methods which include the use of eco-friendly bio control agents.

Gour and Sharma (2010) reported that $S$. rolfsii grew on a wide range of $\mathrm{pH}$ from 4 to 9 but the maximum growth of the fungus was recorded on the medium having $\mathrm{pH}$ value of $6.0(87.00 \mathrm{~mm})$ followed by $\mathrm{pH} 5.0(76.67$ $\mathrm{mm})$, lowest mycelial growth was obtained at $\mathrm{pH} 9.0(28.67 \mathrm{~mm})$ and $\mathrm{pH} 8.0(40.33 \mathrm{~mm})$. $\mathrm{He}$ concluded that optimum $\mathrm{pH}$ for best growth of S. rolfsii lies between pH 6 to 7 .

Shridha Chaurasia (2013) reported that, $\mathrm{pH} 5.0$ was optimum for mycelial growth, while $\mathrm{pH}$ 4.0 to 7.0 were found to be most favourable for the production of sclerotia of $S$. rolfsii and the maximum radial growth of $S$. rolfsii was observed at $\mathrm{pH} 6.5$ followed by $\mathrm{pH} 6.0$ and 7.0 and for formation of sclerotial bodies, it was at $\mathrm{pH}$ 7.0.

Shridha Chaurasia (2014) reported that $\mathrm{pH} 5.0$ was found to be the best and optimum for the production of organic acid by $S$. rolfsii.

Flados (1958) found the reduction in growth of $S$. rolfsii with the increase in soil moisture and also observed that, the organisms can grow from an inoculum source through air dry soils.

Curl (1961) reported abundant population of S. rolfsii at low levels of irrigation than at high levels. 
Reddy and Patil Kulkarni (1972) and Ramarao and Raju (1980) conducted a series of laboratory experiments with $S$. rolfsii isolated from wheat and recorded the highest mortality of seedlings at 25 per cent moisture holding capacity of soil and least per cent disease incidence at 40 per cent soil moisture.

Sclerotia of S. rolfsii survived well at moisture contents up to 75 per cent WHC but at 100 per cent the population declined rapidly and none were recovered after 60 days. The contents of the sclerotia were found to lyse without germination leaving hollow rinds (Satyabrata Maiti and Chitreshwar Sen, 1988). Katti et al., (1983) reported that, the survival of $S$. rolfsii was highest at soil moisture levels between 30 and 50 per cent.

Palakshappa (1986) studied the effect of different soil moisture levels on foot rot of betelvine caused by $S$. rolfsii and reported that, the fungus survived better at low soil moisture than at higher levels. The survival ability was highest between 20 and 40 per cent soil moisture. However, higher saprophytic activity of the fungus was observed at 40 per cent moisture level and the least was at 60 and 70 per cent soil moisture where the saprophytic activity of the fungus was found to be very less.

\section{Materials and Methods}

\section{Soil H-ion concentration (pH)}

Soils with seven different $\mathrm{pH}$ i.e, 6.0, 6.5, 7.0, $7.5,8.0,8.5$ and 9.0 was collected from different fields having desirable $\mathrm{pH}$ levels, then the soil was sterilized in an autoclave and later dried soil of $50 \mathrm{~g}$ with seven different $\mathrm{pH}$ are added in seven different $250 \mathrm{ml}$ cups. In each cup 10 sclerotia were mixed with the soil. Cups are maintained at room temperature. After 10 days the sclerotia were retrieved and placed on PDA for testing their viability.
Three replications are maintained. Number of sclerotia germinated was recorded and germination percentage was calculated using the formula given below.

Per cent germination of sclerotia = $\frac{\text { Number of sclerotia germinated }}{\text { Total number of sclerotia added in cup }} \times 100$

\section{Soil Moisture}

Sandy loam soil of $\mathrm{pH} 6$ was collected, dried and autoclaved for $15 \mathrm{lb}$ p.s.i $\left(121^{\circ} \mathrm{C}\right)$ for 20 minutes. Fifty grams of soil was filled in 250 $\mathrm{ml}$ cups and in each cup 10 sclerotia were added. Four soil moisture regimes i.e. 40, 60, 80 and 100 per cent were maintained at constant temperature of $35^{\circ} \mathrm{C}$. The Soil moisture content was determined using the gravimetric method on an oven-dry basis. The method includes saturation of soil sample followed by removal of available soil moisture by oven drying $\left(100^{\circ} \mathrm{C}-110^{\circ} \mathrm{C}\right)$ until the weight remains constant. After removing from oven, samples were cooled slowly to room temperature and weighed again. The difference in weight was amount of moisture in the soil. The available SMC in the soil was calculated by the following formula:

Soil moisture content (\%) = $\frac{\text { Saturated soil weight - Oven dry soil weight }}{\text { Oven dry soil weight }} \times 100$

The four levels of SMC $(40 \%, 60 \%, 80 \%$ and $100 \%$ ) was adjusted by maintaining the constant weight by regular weighing and replacing the moisture deficit in each cup by watering. Deionized water was used for maintaining the soil moisture content (SMC) in each treatment. After 10 days the sclerotia were retrieved and placed on PDA for testing their viability. Three replications are maintained. Number of sclerotia germinated was recorded and germination percentage was calculated using the following formula. 
Table.1 Influence of soil $\mathrm{pH}$ on the viability of sclerotia of S. rolfsii

\begin{tabular}{|c|c|c|c|c|}
\hline $\begin{array}{c}\text { H-ion } \\
\text { concentration } \\
(\mathbf{p H})\end{array}$ & $\begin{array}{c}\text { Sclerotia } \\
\text { inoculated } \\
\text { (No) }\end{array}$ & $\begin{array}{l}\text { Sclerotia germinated } \\
\text { (No) }\end{array}$ & $\begin{array}{c}\text { Sclerotial } \\
\text { germination } \\
(\%)\end{array}$ & $\begin{array}{c}\text { Per cent } \\
\text { inhibition over } \\
\text { control }\end{array}$ \\
\hline 6.0 & 30 & 26 & $\begin{array}{c}86.60 \\
\left(68.82^{* * *}\right)\end{array}$ & 13.40 \\
\hline 6.5 & 30 & 27 & $\begin{array}{c}90.00 \\
(71.53)\end{array}$ & 10.00 \\
\hline 7.0 & 30 & 29 & $\begin{array}{c}96.66 \\
(83.84)\end{array}$ & 3.34 \\
\hline 7.5 & 30 & 30 & $\begin{array}{l}100.00 \\
(90.00)\end{array}$ & 0.00 \\
\hline 8.0 & 30 & 27 & $\begin{array}{c}90.00 \\
(71.53)\end{array}$ & 10.00 \\
\hline 8.5 & 30 & 25 & $\begin{array}{c}83.33 \\
(66.11)\end{array}$ & 16.67 \\
\hline 9.0 & 30 & 23 & $\begin{array}{l}76.66 \\
(61.19)\end{array}$ & 23.34 \\
\hline $\begin{array}{c}\text { Control } \\
\text { (Native soil =7.2) }\end{array}$ & 30 & 30 & $\begin{array}{l}100.00 \\
(90.00)\end{array}$ & \\
\hline C.D. & - & 0.65 & 8.10 & \\
\hline SE(m) & - & 0.22 & 2.68 & \\
\hline $\mathrm{SE}(\mathrm{d})$ & - & 0.33 & 3.79 & \\
\hline C.V. & - & 4.14 & 5.97 & \\
\hline
\end{tabular}

** Figures in parentheses are angular transformed values

Table.2 Influence of soil moisture on the viability of sclerotia of S. rolfsii

\begin{tabular}{|c|c|c|c|c|}
\hline Moisture (\%) & $\begin{array}{c}\text { Sclerotia } \\
\text { inoculated } \\
(\mathrm{No})\end{array}$ & $\begin{array}{c}\text { Sclerotia } \\
\text { germinated } \\
\text { (No.) }\end{array}$ & $\begin{array}{c}\text { Sclerotial } \\
\text { germination } \\
(\%)\end{array}$ & $\begin{array}{c}\text { Per cent } \\
\text { inhibition over } \\
\text { control }\end{array}$ \\
\hline 40 & 30 & 30 & $\begin{array}{c}100.00 \\
(90.00 * *)\end{array}$ & 0.00 \\
\hline 60 & 30 & 28 & $\begin{array}{c}93.33 \\
(77.69)\end{array}$ & 6.67 \\
\hline 80 & 30 & 27 & $\begin{array}{c}90.00 \\
(71.53)\end{array}$ & 10.00 \\
\hline 100 & 30 & 23 & $\begin{array}{c}76.67 \\
(61.19)\end{array}$ & 23.33 \\
\hline $\begin{array}{c}\text { Control } \\
\text { (50\% moisture) }\end{array}$ & 30 & 30 & $\begin{array}{l}100.00 \\
(90.00)\end{array}$ & \\
\hline C.D. & - & 0.45 & 9.33 & \\
\hline SE(m) & - & 0.15 & 2.92 & \\
\hline SE(d) & - & 0.29 & 4.13 & \\
\hline C.V. & - & 2.83 & 6.48 & \\
\hline
\end{tabular}

\footnotetext{
** Figures in parentheses are angular transformed values
} 
Fig.1 Influence of soil $\mathrm{pH}$ on the viability of sclerotia of $S$. rolfsii after 10 days

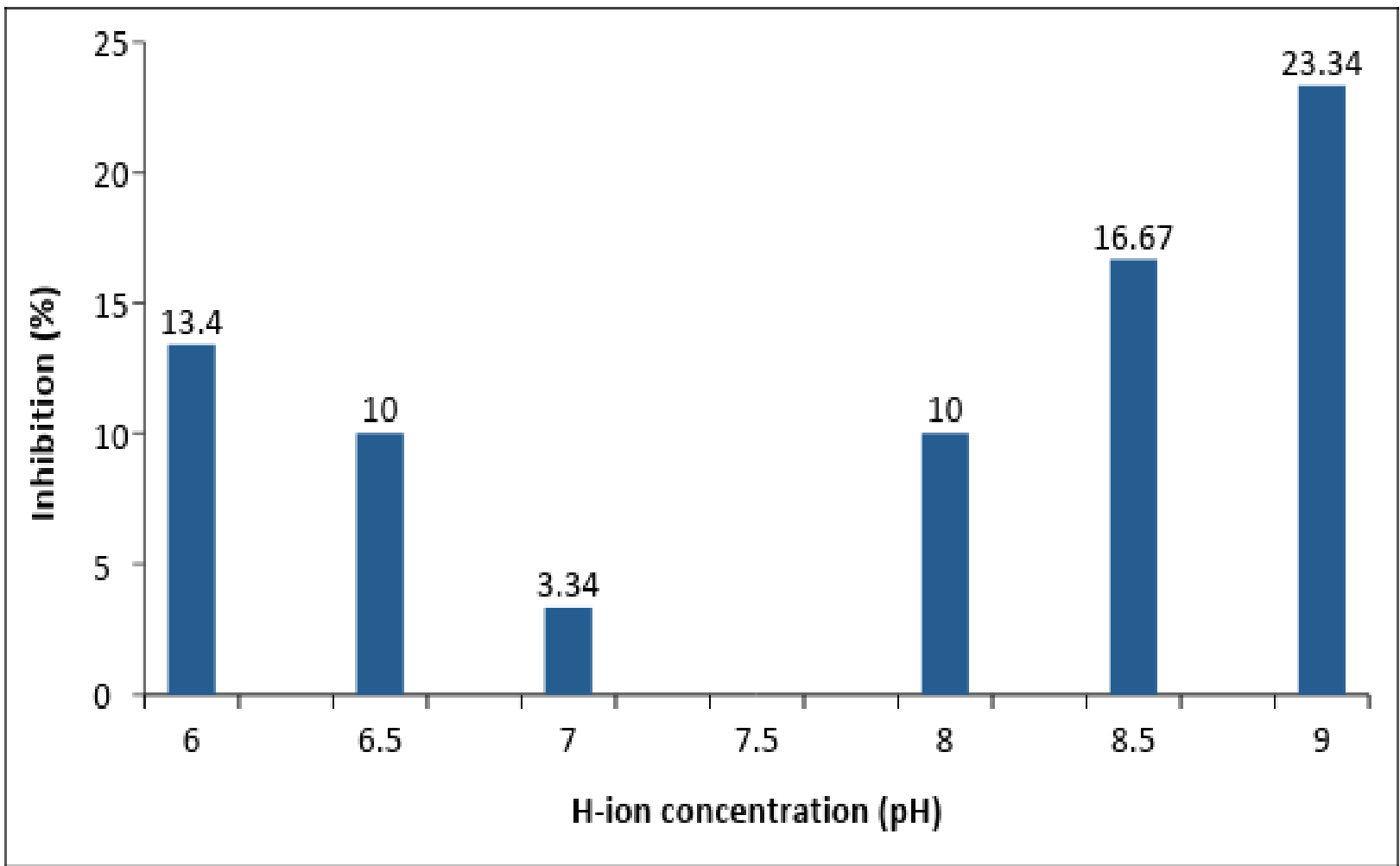

Fig.2 Influence of soil moisture on the viability of sclerotia of S. rolfsii after 10 days

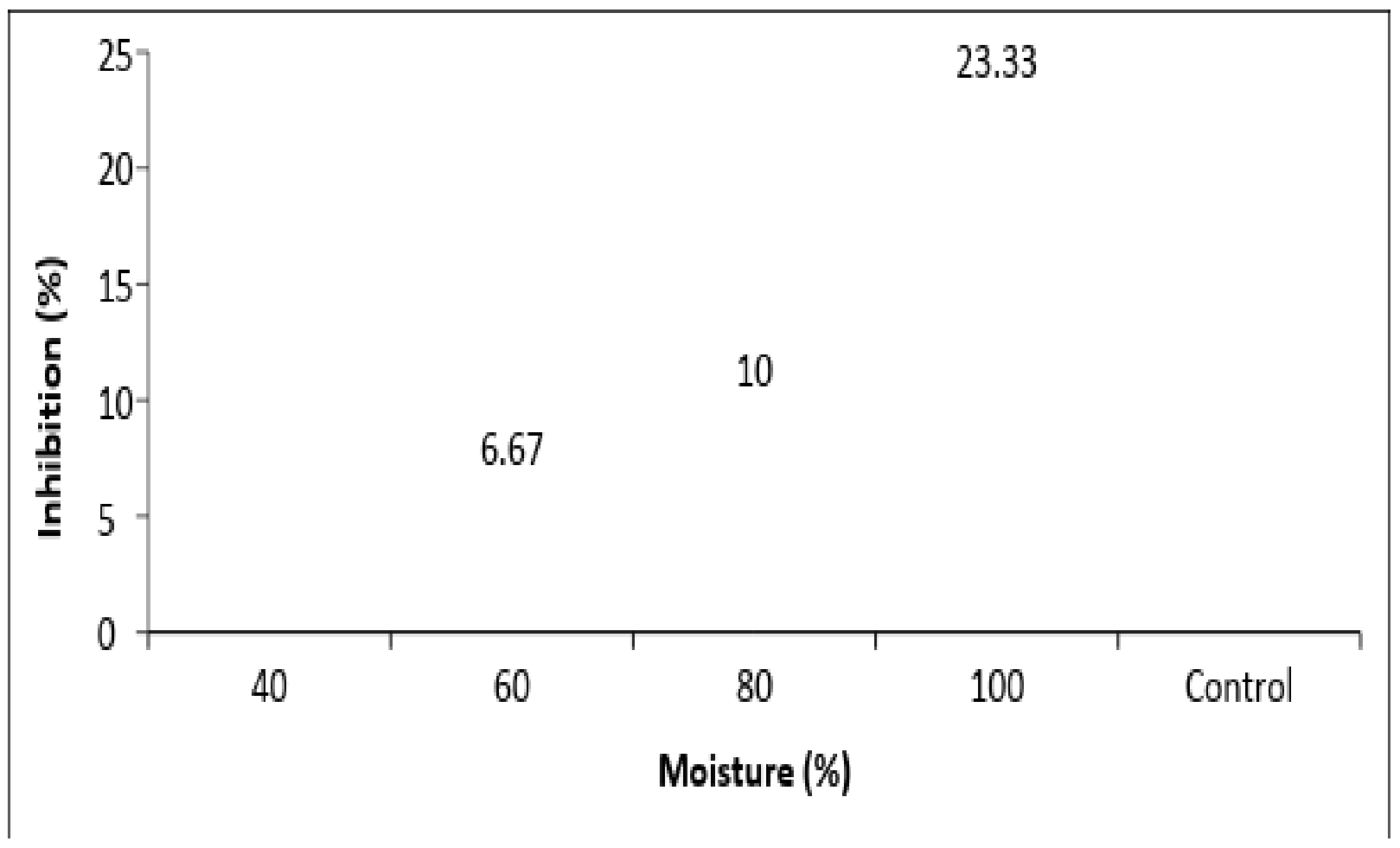


Plate.1 Influence of soil $\mathrm{pH}$ on the viability of sclerotia of $S$. rolfsii after 10 days

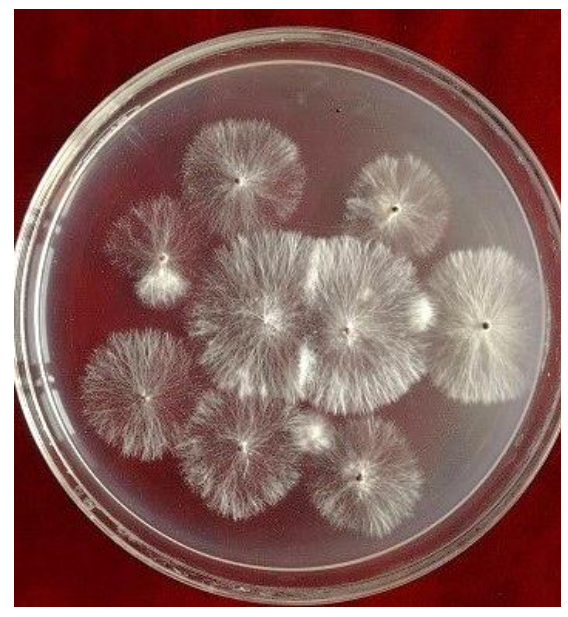

pH 6.0

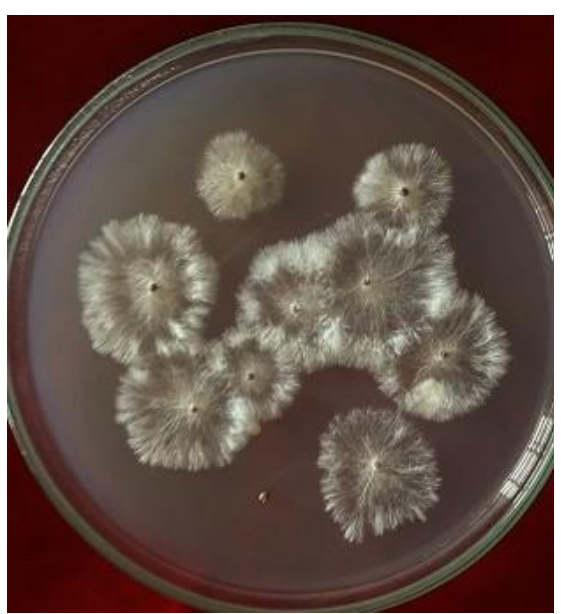

pH 8.0

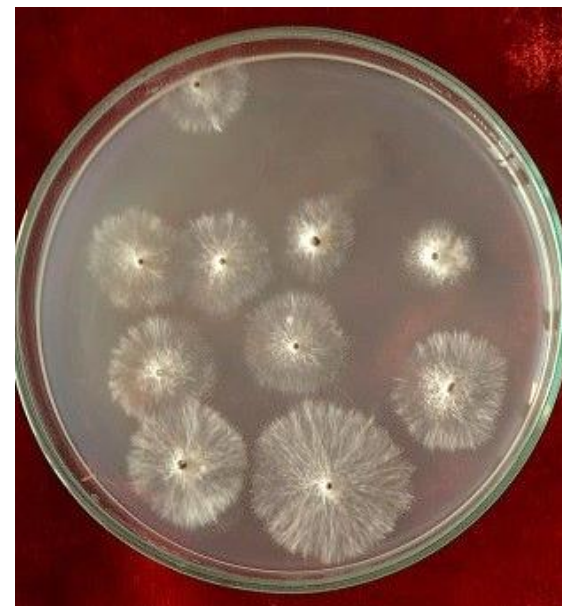

pH 6.5

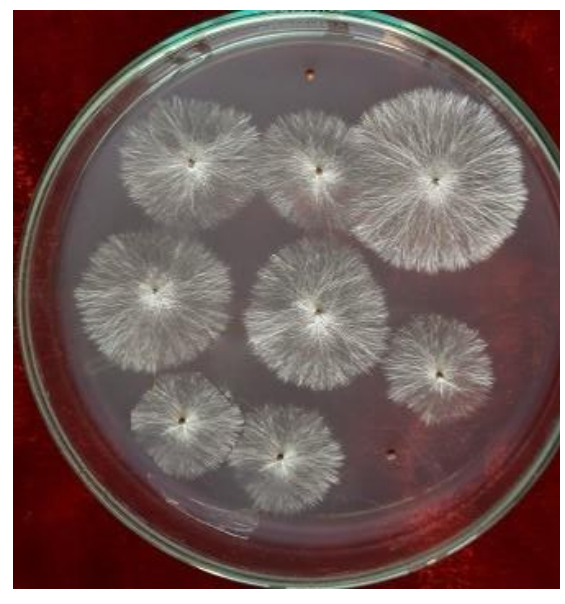

pH 8.5

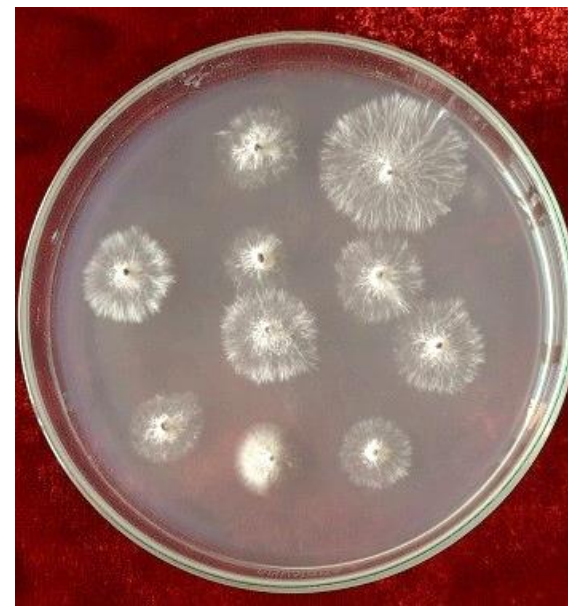

pH 7.0

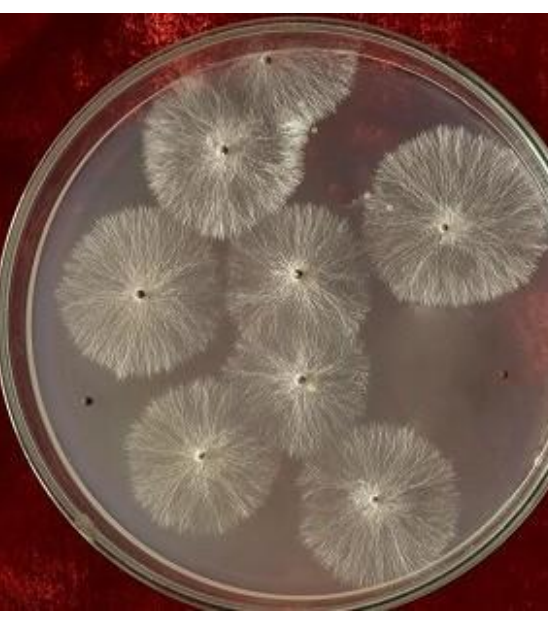

pH 9.0

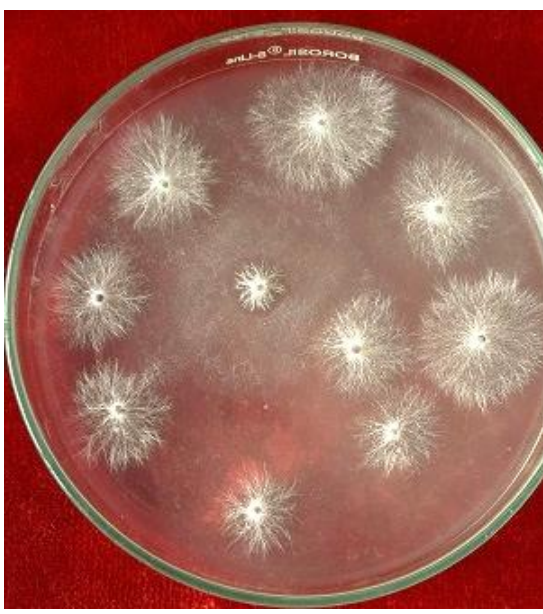

pH 7.5

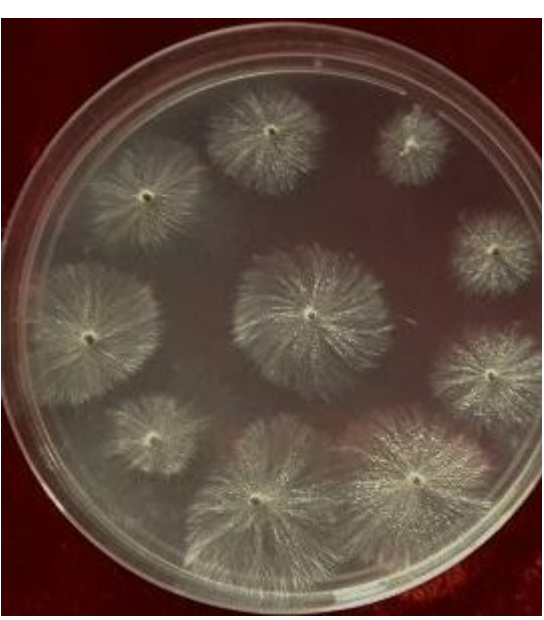

Control 
Plate.2 Influence of soil moisture on the viability of sclerotia of S. rolfsii after 10 days

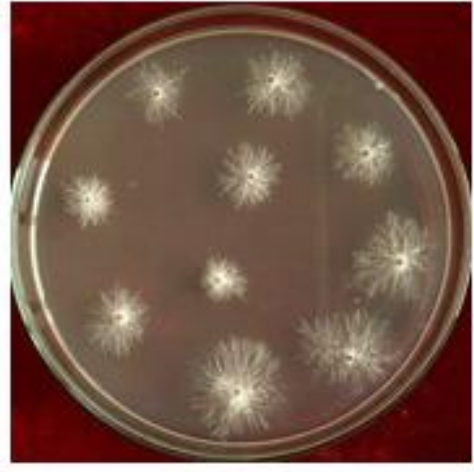

$40 \%$ moisture

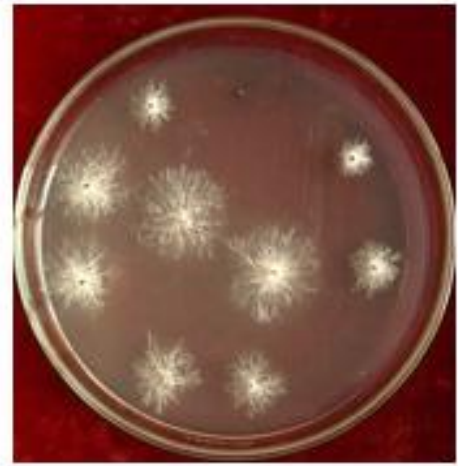

$60 \%$ moisture

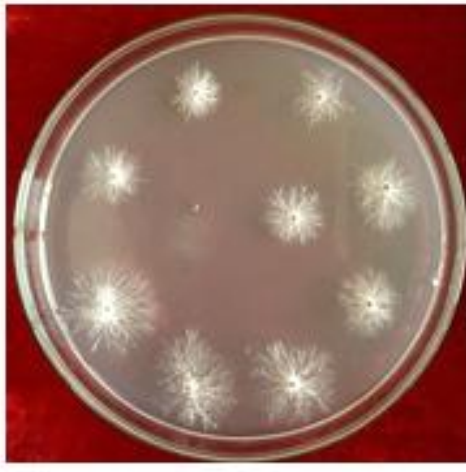

$\mathbf{8 0} \%$ moisture

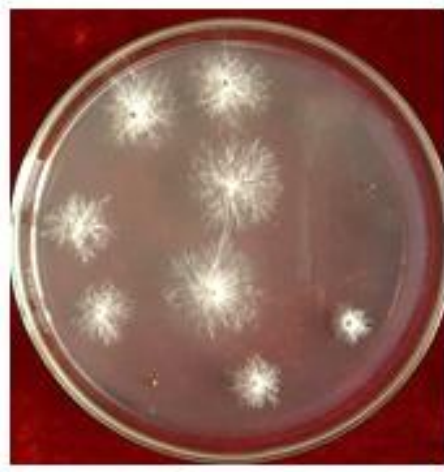

$100 \%$ moisture

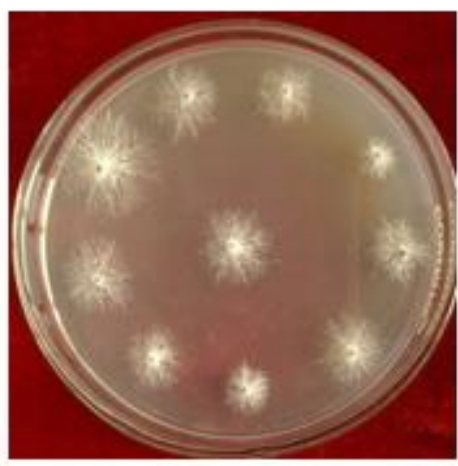

Control
Per cent germination of sclerotia $=$ $\frac{\text { Number of sclerotia germinated }}{\text { Total number of sclerotia added in cup }} \times 100$

\section{Results and Discussion}

\section{Soil H-ion concentration ( $\mathrm{pH})$}

The study of different soil $\mathrm{pH}$ levels on the viability of sclerotia revealed that germination of sclerotia was not affected $(100 \%)$ at $\mathrm{pH} 7.5$ $(100 \%)$ and at par with control i.e., $\mathrm{pH} 7.2$ of the native soil. This clearly indicates that slightly basic $\mathrm{pH}$ is highly congenial for the survival of the sclerotia. Slight reduction in germination percentage $(3.34 \%)$ was observed at neutral $\mathrm{pH}^{\circ}$ and the difference is not significant. Reduction in the survival of sclerotia was observed with reduction in the pH i.e., 90.00 per cent at 6.5 and 86.60 per cent at 6.0 and the difference between them is 3.40 per cent. Highest reduction in germination percentage of sclerotia $(23.34 \%)$ was recorded at $\mathrm{pH} 9.0$ and the difference in sclerotial germination at 8.5 and $9.0 \mathrm{pH}$ is non-significant (Plate 1.1). The results are presented in the Table 1 and Figure 1.

Effect of $\mathrm{pH}$ on sclerotial germination was observed in the following order:

Control $(\mathrm{pH} 7.2)=\mathrm{pH} 7.5=6.5>7.0>8.0>$ $6.0>8.5>9.0$.

Shridha Chaurasia (2013) observed 5.0 as optimum $\mathrm{pH}$ for mycelial growth, while $\mathrm{pH}$ 
4.0 to 7.0 were found to be most favourable for the production of sclerotia of $S$. rolfsii. Gour and Sharma (2010) reported that $S$. rolfsii grew on a wide range of $\mathrm{pH}$ from 4 to 9 but the maximum growth of the fungus was recorded on the medium having $\mathrm{pH}$ value as 6.0 and lowest mycelial growth was obtained at $\mathrm{pH} 9.0$ and $\mathrm{pH}$ 8.0. The present study is in agreement with the earlier studies.

\section{Soil moisture}

Maximum sclerotial germination percentage $(100 \%)$ was observed at 40 per cent soil moisture level and was at par with control (50\% moisture). Increase in the soil moisture resulted in reduction of sclerotial germination percentage was observed. Highest inhibition of sclerotial germination $(23.33 \%)$ was observed at 100 per cent soil moisture and is significantly different with all the soil moisture levels (Plate 1.2). The reduction in sclerotial germination at 40,60 and 80 per cent soil moisture levels is non-significant compared to control. The results are presented in the Table 2 and Figure 2.

Effect of soil moisture on sclerotial germination was observed in the following order:

Control $=40 \%>60 \%>80 \%>100 \%$.

Sclerotia of $S$. rolfsii survived well at moisture contents up to 75 per cent WHC but at 100 per cent the none were recovered after 60 days and the contents of the sclerotia were found to lyse without germination leaving hollow rinds (Satyabrata Maiti and Chitreshwar Sen, 1988). Katti et al., (1983) reported that, the survival of $S$. rolfsii was highest at soil moisture levels between 30 and 50 per cent.

Palakshappa (1986) reported that $S$. rolfsii causing foot rot of betelvine survived better at low soil moisture i.e., between 20 and 40 per cent than at higher levels $(>40 \%)$. The present study also indicated that low soil moisture is suitable for sclerotial germination and also increase in moisture per cent reduced sclerotial germination.

Least sclerotial germination (76.66) occurred at soil $\mathrm{pH} 9.0$ and this indicates that basic $\mathrm{pH}$ is less favorable for sclerotial germination. Moisture levels of 50 per cent (control) and 40 per cent were found to be best for sclerotial germination $(100 \%)$. Least germination $(76.67 \%)$ was observed at 100 per cent moisture, indicating that increase in soil moisture decreases the sclerotial viability.

\section{References}

Aycock, R. 1966. Stem rots and other disease caused by Sclerotium rolfsii. North Carolina Agricultural Experiment Station Technical Bulletin 174: 202.

Chet, I. 1975. Ultra structural basis of sclerotial survival in soil. Microbial Ecology. 2:194-200.

Curl, E.A. 1961. Influence of sprinkler irrigation and four forage crops on population of soil microorganisms including those antagonistic to $S$. rolfsii Sacc. Plant Disease Reporter. 45: 517519.

Flados, N.D. 1958. Ecological factors affecting the growth of Sclerotium rolfsii. Phytopathology. 48: 342.

Gour, H.N and Sharma, P. 2010. Evaluation of fungicides in vitro and in vivo against Sclerotium rolfsii Sacc. caused root rot of groundnut. Indian Phytopathology. 63(3): 352-353.

Higgiens, B.B. 1927. Physiology and parasitism of Sclerotium rolfsii (Sacc.). Phytopathology. 17: 417-448.

Katti, D.V.S., Bhargava, S.N and Shukla, D.N. 1983. Some studies on the saprophytic survival of Sclerotium 
rolfsii in soil. Z. Pflaslsrankh pflpath Pllschute. 90: 382-387.

Khirood, D and Paramjit Kaur, J. 2013. Management of stem rot of groundnut (Arachis hypogaea L.) cultivar in field. Notulae Scientia Biologicae. 5 (3): 316 324.

Kumar, N., Dagla, M.C., Ajay, B.C., Jadon, K.S and Thirumalaisamy. 2013. Sclerotium stem rot: A threat to groundnut production. Popular Kheti. 1 (3): 26-30.

Palakshappa, M.G. 1986. Studies on foot rot of betel vine caused by Sclerotium rolfsii Sacc. in Karnataka. M.Sc. (Ag.) Thesis. University of Agricultural Sciences, Bangalore.

Reddy, M.R and Patil Kulkarni, B.G. 1972. Studies on the influence of soil moisture in foot rot of wheat caused by Sclerotium rolfsii Sacc. Mysore Journal of Agricultural Sciences. 6: 10-13.

Rodriguez-Kabana, R., Backman, P.A and Williams, J.C. 1975. Determination of yield losses due to Sclerotium rolfsii in peanut fields. Plant Disease Reporter. 59: 855-858.

Rolfs, P.H. 1892. The tomato and some of its diseases. Florida University Agricultural Experimental Station Bulletin. 21: 1-38.

Saccardo, P.A. 1911. Notae mycologicae. Annals Mycologici. 9: 249-257.

Satyabrata Maiti and Chitreshwar Sen. 1988. Effect of moisture and temperature on the survival of sclerotia of Sclerotium rolfsii in soil. Journal of Phytopathology. 121: 175-180.

Shridha Chaurasia. 2013. Factors affecting the growth and sclerotial production in Sclerotium rolfsii causing foot rot of brinjal. Indian Journal of Fundamental and Applied Life Sciences. 3 (2): 73-84.

Shridha Chaurasia. 2014. Effect of different factors on organic acid production by Sclerotium rolfsii. International Journal of Pure and Applied Bioscience. 2 (6): $146-153$.

\section{How to cite this article:}

Raghavendra, B., T. Srinivas and Padmodaya, B. 2018. Influence of Soil pH and Moisture on the Viability of Sclerotia of S. rolfsii.Int.J.Curr.Microbiol.App.Sci. 7(08): 92-100. doi: https://doi.org/10.20546/ijcmas.2018.708.011 